\title{
Effect on blood volume of maintaining a high central venous pressure after major aortic valve surgery
}

\author{
DAVID C. FLUCK ${ }^{1}$, L. LOPEZ BESCOS, and R. GILKES \\ Department of Cardiology, Guy's Hospital
}

\begin{abstract}
Fluck, D. C., Lopez Bescos, L., and Gilkes, R. (1973). Thorax, 28, 762-767. Effect on blood volume of maintaining a high central venous pressure after major aortic valve surgery. Serial blood volume measurements were made in 15 patients undergoing major aortic valve surgery requiring cardiopulmonary bypass. In all patients the plasma volume was measured by iodine-125 ( $\left.{ }^{125} \mathrm{I}\right)$ labelled albumin and in 10 the red cell mass was measured by chromium- 51 $\left({ }^{51} \mathrm{Cr}\right)$ labelled red cells. Close correlation was found between the blood volume derived from the plasma volume and central venous haematocrits and the blood volume derived by addition of the plasma volume and red cell mass. Postoperatively blood was given to maintain the right atrial pressure at between 10 and $15 \mathrm{~cm} \mathrm{H}_{2} \mathrm{O}$. Before operation the red cell mass, and plasma and blood volumes related to body weight were within the normal range. In the postoperative phase the first measurement two hours after the end of the operation showed a significant decrease in mean blood volume, red cell mass, and plasma volume as compared with the preoperative level. By the second postoperative measurement six hours after the end of operation the mean blood volume had risen to the preoperative level. Subsequently, over postoperative days 1 to 6 the mean blood volume remained steady, although the red cell mass tended to fall. After blood transfusion had ceased the red cell mass usually showed a progressive fall. It was considered that although there was little relationship between the right atrial pressure and the blood volume there was little or no clinical value in performing serial postoperative measurements of blood volume in addition to venous pressure monitoring in these patients.
\end{abstract}

The maintenance of a correct blood volume after major cardiac surgery is of considerable importance as marked deviation from the normal volume can seriously impair cardiorespiratory function (Berger, Boyd, and Marcus, 1964). At Guy's Hospital it was the policy to control the blood transfusion requirements postoperatively by maintaining a high central venous pressure. Blood was given to the patients immediately on cessation of bypass until the right atrial pressure had reached a level of between 10 and $15 \mathrm{~cm} \mathrm{H}_{2} \mathrm{O}$. If the cardiac output remained adequate, as judged by the usual clinical signs, no further blood was given. Later, if necessary, more blood was given to maintain the venous pressure at about this level. The aim of this investigation was to find out what changes occurred in the blood volume following aortic valve surgery when this method of management was used.

1Requests for reprints: Dr. D. C. Fluck, Central Middlesex Hospital, London NW10 7NS.

\section{PATIENTS AND METHODS}

Fifteen patients who underwent aortic valve surgery were investigated. There were $14 \mathrm{men}$ and one woman. Thirteen had aortic valve replacement with either a Starr or homograft valve, one had both aortic and mitral valve replacements, and one had a repair of a leaking aortic Starr valve (Table I). Their ages ranged from 50 to 65 years, the average being 60 years. Before operation all these patients were seriously ill, with clinical and haemodynamic evidence of left ventricular failure. The operations were all carried out under normothermic cardiopulmonary bypass. The pump used was a British American Optical Co. roller pump with a Temptrol

T A B LE I

\begin{tabular}{|c|c|c|c|}
\hline & No. & Females & Males \\
\hline $\begin{array}{l}\text { Aortic valve replacement } \\
\text { Repair of leaking Starr valve } \ldots\end{array}$ & $\begin{array}{r}13 \\
1 \\
1\end{array}$ & $\underline{-}$ & $\begin{array}{r}12 \\
1 \\
1\end{array}$ \\
\hline Total $\quad \ldots$ & 15 & 1 & 14 \\
\hline
\end{tabular}


or Rygg-Kyvsgaard oxygenator. The pump was primed with 1-2 litres of $5 \%$ dextrose and during the operation all blood loss was carefully measured. At the end of the operation blood was given from the pump to the patients as indicated previously. After the operation the requirement for blood was judged on the basis of maintaining the mean right atrial pressure at between 10 and $15 \mathrm{~cm} \mathrm{H}_{2} \mathrm{O}$. During this period the plasma volume was measured by a dilution method using ${ }^{125}$ I labelled albumin (Veall and Vetter, 1958). In the serial measurements of plasma volume increasing amounts of radioactive albumin were given to the patient. Blood samples were taken from the patients' pulmonary arteries 10 , 20 , and 30 minutes or 10 and 20 minutes only after the injection. The red cell mass was measured by the use of ${ }^{51} \mathrm{Cr}$ labelled red cells (Veall and Vetter, 1958), an increasing dosage of radioactivity again being given in the serial measurements. Samples were withdrawn after 10,20 , and 30 minutes. The haematocrit was determined by a micro Hawksley centrifuge and no correlation for trapped plasma was made. The right atrial pressure was measured by a water manometer, the zero reference point being taken as the mid-thoracic point. The measurements of plasma volume and red cell mass were made on the day before operation, twice on the day of operation, two and six hours after the operation, and then on days $1,2,3$, and 6 . Careful records were kept of the blood balance in the first 24 to 48 hours.

\section{RESULTS}

Before and after the operation there were only small differences between the mean red cell mass measured 10, 20, and 30 minutes after injection of ${ }^{15} \mathrm{Cr}$ (Fig. 1). Consequently, the red cell mass at each measurement period was calculated by averaging the results derived from the three blood samples.

The plasma volume was measured by taking blood samples at either 10 or 20 minutes after the intravenous injection of ${ }^{125}$ I labelled albumin or at 10,20 , and 30 minutes. The mean albumin space derived from the 20 and 30 minute samples expressed as a percentage of the value derived from the 10 minute sample is shown for the preoperative day, operation day, and postoperative days 1 to 6 (Fig. 2). No significant difference was found in the 20 and 30 minute values between the samples obtained before and after the operation. Thus there was no evidence after the operation that albumin was leaking more quickly from the intravascular space after the injection of the ${ }^{125} \mathrm{I}$ labelled albumin. Hence the mean albumin space was derived from that measured at 10,20, and 30 minutes after injection, and a standard correction for leakage of albumin

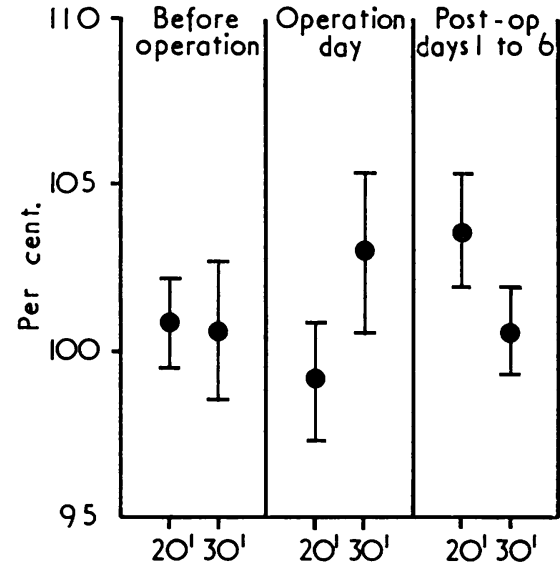

FIG. 1. Mean red cell mass $\pm S E$ for the 20 and 30 minute blood samples expressed as a percentage of the 10 minute sample. The 20 minute sample for post-operative days 1 to 6 is significantly greater $(\mathrm{P}<0.05)$ than the 10 minute sample. No significant difference between 10, 20, and 30 minute samples in the other cases.

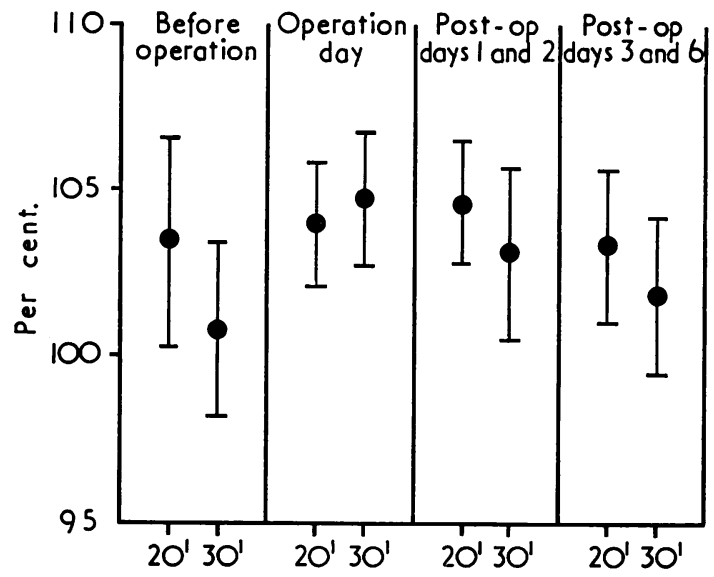

FIG. 2. Mean albumin space $\pm S E$ for the 20 and 30 minute blood samples expressed as a percentage of the 10 minute sample. No significant difference in the mean albumin space at 20 and 30 minutes between the results obtained before and after operation.

from the intravascular space was applied to calculate the plasma volume (Veall and Vetter, 1958). This method was used as three readings were found to be insufficient to produce an accurate extrapolation line for each individual measurement.

The whole body/central venous haematocrit ratio was found to fall in the normal range before the operation and on the operation day, but 
about half the later measurements on postoperative days 1, 2, and 6 were low (Fig. 3). However, despite this there was a close correlation between the blood volume values derived from the plasma volume and central venous haematocrit and the blood volume values derived by addition of the plasma volume and red cell mass (Fig. 4). In view of this, where the red cell mass was not directly measured the blood volume was calculated

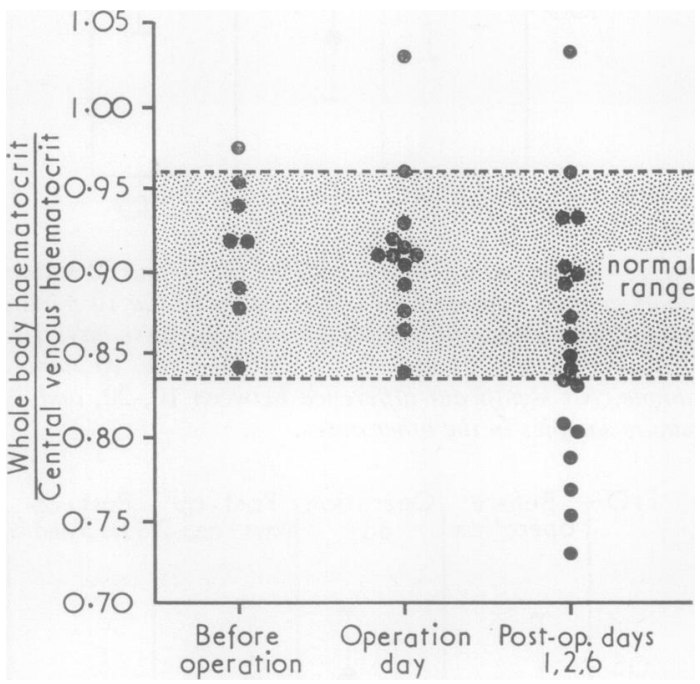

FIG. 3. The whole body/central venous haematocrit ratio. The normal range is according to Chaplin, Mollison, and Vetter (1953).

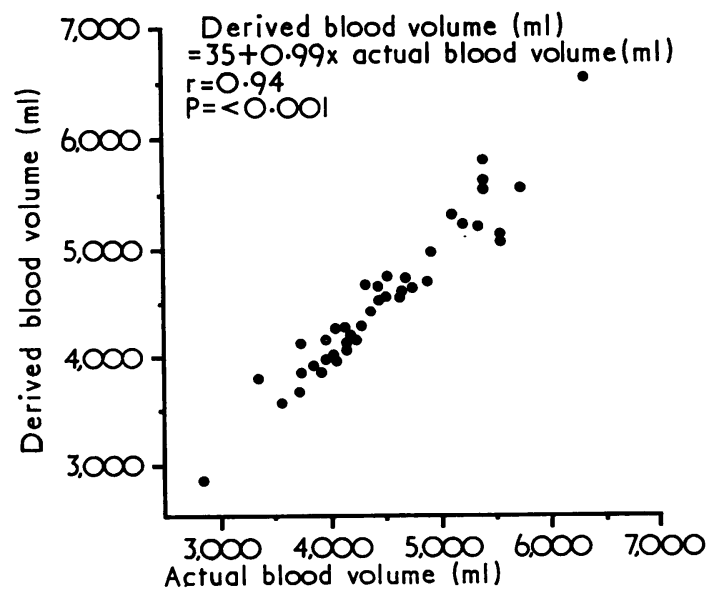

FIG. 4. Blood volume derived from plasma volume and central venous haematocrit shows close correlation with the actual blood volume calculated by the addition of plasma volume and red cell mass, both measured directly.
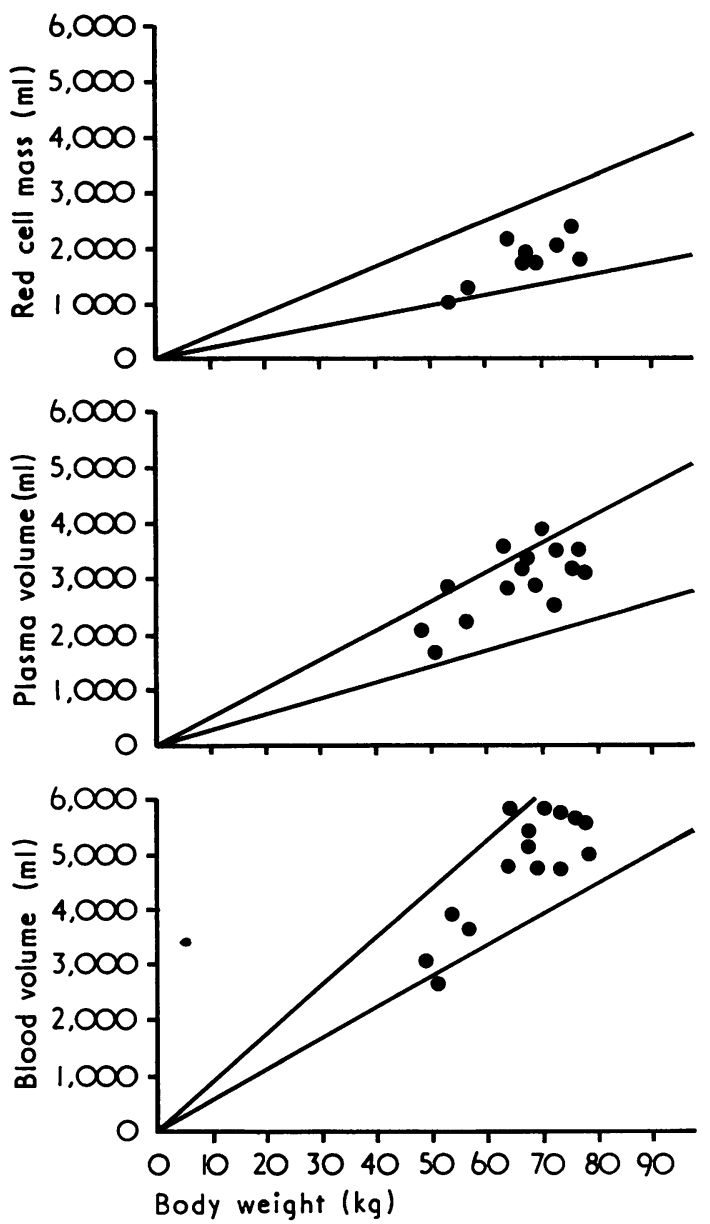

FIG. 5. Volume of the red cell mass, plasma volume, and blood volume related to body weight before the operation. The lines represent range of normality, according to Gray and Frank (1953).

from the plasma volume and central venous haematocrit. In one instance the blood volume was derived from the red cell mass and central venous haematocrit.

The red cell mass, plasma volume, and blood volume of the patients before operation were related to body weight (Fig. 5). All the measurements of blood volume, red cell mass, and plasma volume were within, or only just outside, the normal range $(\mathrm{ml} / \mathrm{kg})$ as found by Gray and Frank (1953).

The first measurements two hours after the end of the operation showed a significant decrease in the mean blood volume, red cell mass, and plasma volume as compared with the pre- 
operative levels (Table II). By the second postoperative measurement six hours after the end of the operation the mean blood volume had risen to the preoperative level. Subsequently, over postoperative days 1 to 6 , the mean blood volume remained steady, although the mean red cell mass tended to fall and was significantly less than the preoperative level by postoperative day 6. There was considerable scatter in the changes in blood volume between individual patients, the blood volume on the operating day ranging from 70 to $139 \%$ of the preoperative value.

T A B LE I I

\begin{tabular}{|c|c|c|c|c|c|c|c|c|}
\hline \multirow{2}{*}{ Measurement } & \multirow{2}{*}{ Units } & \multirow{2}{*}{ Preop. } & \multirow{2}{*}{ OD 1} & \multirow{2}{*}{ OD 2} & \multicolumn{4}{|c|}{ Postoperative Day } \\
\hline & & & & & 1 & 2 & 3 & 6 \\
\hline Plasma volume & $\begin{array}{l}\mathrm{ml} / \mathrm{kg} \\
\text { SD } \pm \\
\text { No. } \\
\% \text { of } \\
\text { preop. } \\
\text { value } \\
\text { SD } \pm \\
\text { No. }\end{array}$ & $\begin{array}{r}45 \\
7 \\
15 \\
100 \\
= \\
-\end{array}$ & $\begin{array}{c}39 \\
6 \\
13 \\
\\
89 \\
13 \\
13\end{array}$ & $\begin{array}{r}46 \\
10 \\
13 \\
\\
101 \\
12 \\
13\end{array}$ & $\begin{array}{r}50 \\
11 \\
13 \\
\\
\\
112 \\
21 \\
13\end{array}$ & $\begin{array}{r}49 \\
12 \\
10 \\
\\
116 \\
40 \\
10\end{array}$ & $\begin{array}{r}51 \\
8 \\
8 \\
\\
116 \\
33 \\
8\end{array}$ & $\begin{array}{r}51 \\
12 \\
10 \\
\\
116 \\
29 \\
10\end{array}$ \\
\hline Red cell mass & $\begin{array}{l}\mathrm{ml} / \mathbf{k g} \\
\mathrm{SD} \pm \\
\text { No. } \\
\% \text { of } \\
\text { preop. } \\
\text { value } \\
\text { SD } \pm \\
\text { No. }\end{array}$ & $\begin{array}{r}27 \\
5 \\
9 \\
100 \\
=\end{array}$ & $\begin{array}{r}21 \\
2 \\
7 \\
\\
80 \\
13 \\
7\end{array}$ & $\begin{array}{r}26 \\
7 \\
6 \\
\\
104 \\
42 \\
6\end{array}$ & $\begin{array}{r}24 \\
5 \\
9 \\
\\
94 \\
18 \\
8\end{array}$ & $\begin{array}{r}23 \\
7 \\
6 \\
\\
90 \\
19 \\
5\end{array}$ & $=$ & $\begin{array}{r}78 \\
14 \\
5\end{array}$ \\
\hline Blood volume & $\begin{array}{l}\text { ml/kg } \\
\text { SD } \pm \\
\text { No. } \\
\% \text { of } \\
\text { preop. } \\
\text { value } \\
\text { SD } \pm \\
\text { No. }\end{array}$ & $\begin{array}{l}71 \\
10 \\
15 \\
100 \\
=\end{array}$ & $\begin{array}{r}60 \\
8 \\
13 \\
\\
\\
86 \\
15 \\
13\end{array}$ & $\begin{array}{r}71 \\
15 \\
13 \\
\\
100 \\
17 \\
13\end{array}$ & $\begin{array}{r}74 \\
14 \\
14 \\
\\
\\
104 \\
104 \\
14 \\
14\end{array}$ & $\begin{array}{r}73 \\
16 \\
10 \\
\\
\\
105 \\
32 \\
10\end{array}$ & $\begin{array}{r}75 \\
11 \\
8 \\
\\
109 \\
29 \\
8\end{array}$ & $\begin{array}{l}76 \\
19 \\
10\end{array}$ \\
\hline $\begin{array}{c}\text { Right atrial } \\
\text { pressure }\end{array}$ & $\begin{array}{l}\mathrm{cm}_{\mathrm{H}_{2} \mathrm{O}} \\
\mathrm{SD}_{ \pm} \\
\text {No. }\end{array}$ & $\begin{array}{r}12 \\
6 \\
15\end{array}$ & $\begin{array}{r}10 \\
3 \\
13\end{array}$ & $\begin{array}{l}12 \\
13\end{array}$ & $\begin{array}{r}13 \\
2 \\
14\end{array}$ & $\begin{array}{r}11 \\
3 \\
10\end{array}$ & $\begin{array}{l}9 \\
3 \\
8\end{array}$ & $\begin{array}{r}10 \\
2 \\
10\end{array}$ \\
\hline
\end{tabular}

Mean plasma volume, red cell mass, and right atrial pressure were measured before the operation (Preop.), on the day of the operation (OD 1 and 2) two and six hours after the operation, and on postoperative days $1,2,3$, and 6 . The units for the PV, RCM, and blood volume are expressed in $\mathrm{ml} / \mathrm{kg}$, and as a percentage of the preoperative value. On the operation day, two hours after the operation (OD 1) the plasma volume $(P<0.01$ and $P<0.025)$, red cell mass $(P<0.005$ and $P<0.01)$, and blood volume $(P<0.005$ and $P<0.005)$ are significantly less than the preoperative value (P values for units $(\mathrm{ml} / \mathrm{kg})$ and percentage preoperative values respectively). On postoperative day 6 , the red cell mass was significantly less $(P<0.01$ and $P<0.01$ for $\mathrm{ml} / \mathrm{kg}$ the red cell mass was significantly less $(P<0.01$ and $P<0.01$ for $\mathrm{m} / \mathrm{kg}$ value.

Note. Red cell mass was measured in 10 patients but only in nine preoperatively. This explains the difference in numbers (No.) on postoperative days 1 and 2 between the red cell mass expressed in $\mathrm{ml} / \mathrm{kg}$ and percentage of preoperative value.

The policy after the operation was to transfuse blood into the patient to try to maintain the right atrial pressure at $10-15 \mathrm{~cm} \mathrm{H}_{2} \mathrm{O}$, but despite this the mean atrial pressure two hours after the operation was only $10 \mathrm{~cm} \mathrm{H}_{2} \mathrm{O}$ but rose to $12 \mathrm{~cm} \mathrm{H}_{2} \mathrm{O}$ after six hours (Table II). There was little or no direct relationship on the operating day between the mean right atrial pressure and

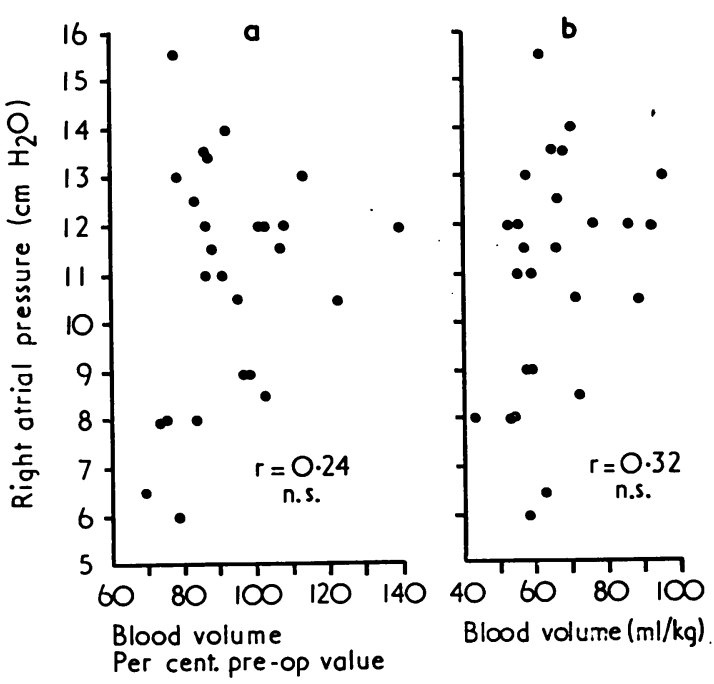

FIG. 6. Relationship between the right atrial pressure and blood volume expressed as (a) a percentage of the preoperative level and (b) in $\mathrm{ml} / \mathrm{kg}$ on the day after the operation. No significant correlation was demonstrated.

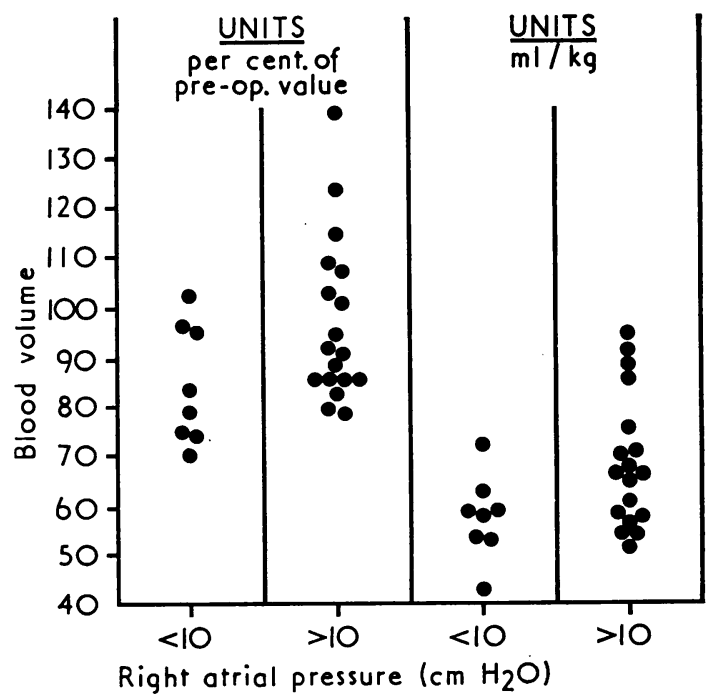

FIG. 7. Blood volume on the day after the operation, when the mean right atrial pressure was less than and greater than $10 \mathrm{~cm} \mathrm{H}_{2} \mathrm{O}$. The mean $\pm S D$ blood volume when the $\mathrm{RAP}$ was above $10 \mathrm{~cm} \mathrm{H}_{2} \mathrm{O}(69 \pm 14 \mathrm{ml} / \mathrm{kg} 97 \% \pm 16 \mathrm{per}-$ centage preoperation value) was significantly greater $(\mathrm{P}=0.02$ and $\mathrm{P}=0.05$ respectively) than when it was below $10 \mathrm{~cm} \mathrm{H}_{2} \mathrm{O}(58 \pm 8 \mathrm{ml} \mathrm{kg}$ and $85 \% \pm 12$ percentage preoperation value). 

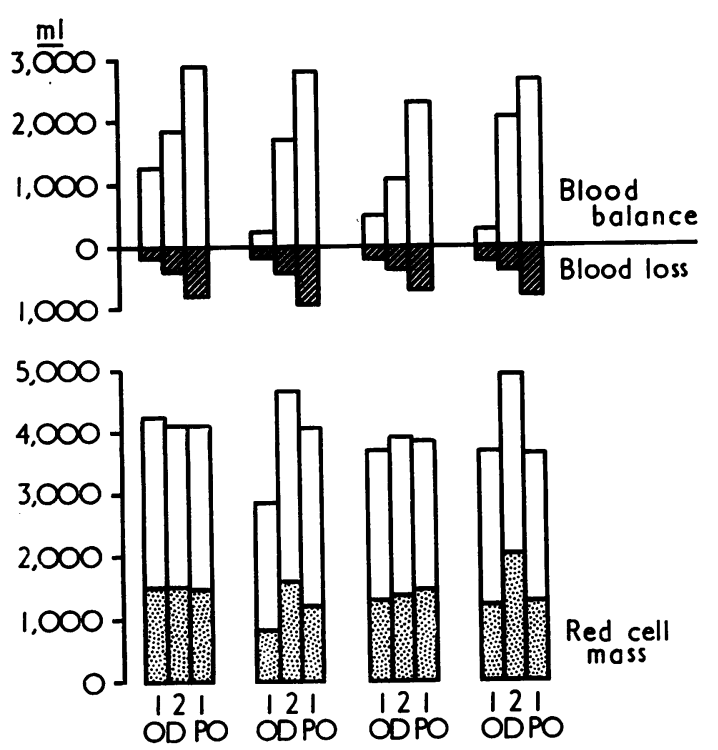

FIG. 8. Relationship of the blood balance to the changes in red cell mass and blood volume (plasma volume +red cell mass, both measured directly) in the early postoperative phase (4 patients).

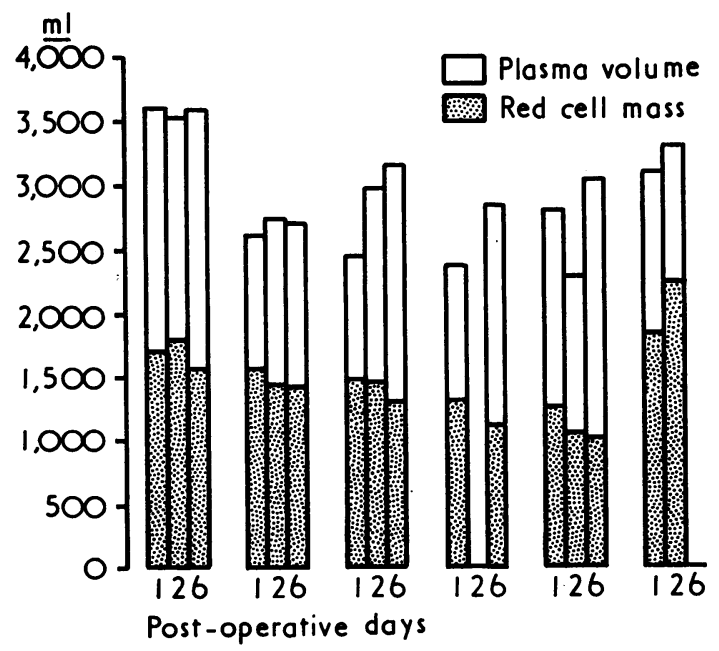

FIG. 9. Changes in blood volume (plasma volume+red cell mass, both measured directly) and red cell mass on postoperative days 1, 2, and 6 after cessation of blood transfusion ( 6 patients). the blood volume (Fig. 6). However, when the right atrial pressure fell below $10 \mathrm{~cm} \mathrm{H}_{2} \mathrm{O}$ the blood volume was between 70 and $102 \%$ of the preoperative value, whereas when the right atrial pressure was above $10 \mathrm{~cm} \mathrm{H}_{2} \mathrm{O}$ the blood volume was significantly higher, ranging from 78 to $139 \%$ of the preoperative value (Fig. 7).

The blood volume and red cell mass bore no relationship at all to the blood balance, large positive blood balances not being associated with corresponding rises in blood volume and red cell mass (Fig. 8). After blood transfusion had ceased the red cell mass usually showed a progressive fall (Fig. 9).

\section{DISCUSSION}

This study has shown that the policy of controlling blood transfusion requirements by maintaining the mean right atrial pressure at a level of $10-15 \mathrm{~cm} \mathrm{H}_{2} \mathrm{O}$ after major aortic valve surgery will restore the average blood volume to the preoperative level six hours from the end of the operation. Possibly the reason for the deficit at two hours after the operation was that the average of the mean right atrial pressure was in fact only $10 \mathrm{~cm} \mathrm{H}_{2} \mathrm{O}$ and that in many cases the right atrial pressure was not being maintained at a high enough level. The study also showed that to have relied on the blood balance as a means of judging the blood transfusion requirement would undoubtedly have led to serious hypovolaemia. The corresponding changes in blood balance and red cell mass indicated that red cells were disappearing rapidly from the circulation, the patient usually developing a particularly low red cell mass by postoperative day 6. It is possible that this loss of red cells may have been due to concealed internal bleeding, haemolysis or sequestration. Sequestration of red cells has been observed to be common after major cardiac surgery (Litwak, Slonim, Wisoff, and Gadboys, 1963), but there was no evidence of slow mixing of red cells in our study. A possible explanation was that transfused red cells and the red cells subjected to cardiopulmonary bypass have a shortened life span.

Although it has been claimed that the rate of diffusion of protein across the capillary membrane is accelerated by anaesthesia, hypoxia, and trauma (Albert, Gravel, Turmel, and Albert, 1965), in the present study there was no evidence of any increase in the rate of leakage of albumin from the intravascular space after the operation. This, of course, supports the claim that measurements of the plasma volume after a cardiac 
operation by the use of a standard correction for the albumin leak are valid (Knott and Kirklin, 1967). It was found that although the whole body/central venous haematocrit ratio was in the normal range on the preoperative and operation days, it was often low on postoperative days 1,2 , and 6 . In view of the absence of any evidence that there was any increased leakage from the intravascular space, it is unlikely that this is due to a systematic overestimation of the plasma volume and suggests that the haematocrit in the capillary blood is relatively low (Chaplin, Mollison, and Vetter, 1953). On the other hand, Swan and Nelson (1971) have presented strong evidence that albumin leaks rapidly from the intravascular space in the first few minutes after injection and that the plasma volume is thus consistently overestimated by this method. It is thus possible that this early leak may be excessive and hence results in even further overestimation of the plasma volume, so explaining the low whole body/central venous haematocrit ratio. However, despite this, the blood volume derived from the plasma volume and central venous haematocrit correlated well with the blood volume calculated from direct measurements of plasma volume and red cell mass.

Although overall this method of maintaining blood volume appears to be satisfactory there was wide variation of blood volume from patient to patient. This reflected the absence of any close correlation between the blood volume and right atrial pressure. This no doubt is related to a marked difference in venous tone and right ventricular function between the patients, factors which also affect the right atrial pressure (Landis and Hortenstine, 1950). The only way to obtain a finer control of the blood volume would be to carry out frequent blood volume measurements. However, it is doubtful if this would be an advantage since the filling pressure of the heart is probably of more importance than the blood volume in influencing cardiac function (MacLean and Duff, 1965). It has been found that after open-heart surgery for acquired valvular disease of the heart the right atrial pressure bears no consistent relationship to the left atrial pressure (Sarin, Yalav, Clement, and Braimbridge, 1970). Hence it would seem an advantage that the filling pressure of both the left and right sides of the heart be monitored and controlled.

We wish to thank Mr. D. Ross and Mr. A. Yates for allowing us to study their patients.

\section{REFERENCES}

Albert, S. N., Gravel, Y., Turmel, Y., and Albert, C. A. (1965). Pitfalls in blood volume measurement. Anesthesia and Analgesia, 44, 805.

Berger, R. L., Boyd, T. F., and Marcus, P. S. (1964). A pattern of blood-volume responses to open-heart surgery. New England Journal of Medicine, 271, 59.

Chaplin, H., Mollison, P. L., and Vetter, H. (1953). The body/venous hematocrit ratio: its constancy over a wide hematocrit range. Journal of Clinical Investigation, 32, 1309.

Gray, S. J. and Frank, H. (1953). The simultaneous determination of red cell mass and plasma volume in man with radioactive sodium chromate and chromic chloride. Journal of Clinical Investigation, 32, 1000.

Knott, H. W. and Kirklin, J. W. (1967). Validity of comparisons of plasma volumes before and after operation. Surgery, 62, 843.

Landis, E. M. and Hortenstine, J. C. (1950). Functional significance of venous blood pressure. Physiological Reviews, 30, 1.

Litwak, R. S., Slonim, R., Wisoff, B. G., and Gadboys, H. L. (1963). Homologous-blood syndrome during extracorporeal circulation in man. New England Journal of Medicine, 268, 1377.

MacLean, L. D. and Duff, J. H. (1965). Use of central venous pressure as a guide to volume replacement in shock. Diseases of the Chest, 48, 199.

Sarin, C. L., Yalav, E., Clement, A. J., and Braimbridge, M. V. (1970). The necessity for measurement of left atrial pressure after cardiac valve surgery. Thorax, 25, 185.

Swan, H., and Nelson, A. W. (1971). Blood volume I. Annals of Surgery, 173, 481.

Veall, N. and Vetter, H. (1958). Radioisotope Techniques in Clinical Research and Diagnosis. Butterworth, London. 